\title{
The application prospects and development trends of orally disintegrating tablets to dogs
}

\section{Tingting $\mathbf{Y i}^{1,2}$}

${ }^{1}$ Qingdao University of Science \& Technology, Department of Pharmaceutical Engineering, no. 53, Zhengzhou Road, Shibei District, 266042 , Qingdao, Shandong Province, China. E-mail: yitingting_0@163.com. Corresponding author.

${ }^{2}$ Shandong Agricultural University, Faculty of Technology and Animal Science, Department of Veterinary Medicine, Taian, Shandong, China.

\begin{abstract}
Orally disintegrating tablets (ODTs) disintegrate rapidly in the mouth in seconds when placed at the tongue. The introduction of ODTs for dogs can address many needs, ranging from convenient dosing for dogs with dysphagia to extending life cycle of drugs. Now, different technologies are widely combined for developing ODTs. The combination makes ODTs have more properties, obtaining orally disintegrating sustained release tablets or orally disintegrating enteric tablets or enhancing the dissolution rate and bioavailability of poorly water-soluble drugs and so on. The aim of this article is to give a comprehensive prospect to the application of ODTs to dogs, including ideal properties of drugs, indications of ODTs, considerations in developing ODTs and development trends of ODTs for dogs.

Key words: orally disintegrating tablet, indication, consideration, dogs.
\end{abstract}

As perspectivas de aplicação de comprimidos com capacidade de desintegração por via oral aos cães

RESUMO: Os comprimidos de desintegração oral (ODTs) se desintegram rapidamente na boca em questão de segundos, quando colocados na língua. A introdução de ODTs para cães pode resolver muitas necessidades, que vão desde a dosagem conveniente para cães com disfagia à extensão do ciclo de vida de drogas. Hoje, diferentes tecnologias são amplamente usadas para desenvolver ODTs. A combinação torna ODTs com mais propriedades e obter comprimidos de desintegração oral de libertação sustentada ou comprimidos de desintegração oral entéricos ou melhorar a velocidade de dissolução e biodisponibilidade de drogas pouco solúveis em água e assim por diante. O objetivo deste artigo é dar uma perspectiva abrangente para a aplicação de ODTs para cães, incluindo a indicação das ODTs, considerações em ODTs em desenvolvimento, desenvolvimentos de ODTs para cães.

Palavras-chave: por via oral de desintegração de comprimidos, indicação, consideração, cães.

\section{INTRODUCTION}

In the companion animal market, the owner convenience is responsible for the product acceptance. In the 1999 American Association of Pharmaceutical Scientists (AAPS) meeting, pharmaceutical scientists pointed out that one major area of drug delivery needs in animal health was convenient delivery for companion animals (IMRAN et al., 2002). Oral administration is preferred for dogs compared to injections and many other routes because of convenience and compliance. Palatable tablets are commonly used. However, dogs with dysphagia have difficulties in swallowing these conventional tablets. The need has resulted in the launch of orally disintegrating tablets (ODTs) for dogs.
ODTs disintegrate in the oral cavity without water within 60 seconds or less. ODTs are also called as orodispersible tablets, fast disintegrating tablets, fast dissolving tablets, mouth dissolving tablets and so on (HIRANI et al., 2009).

United States Food and Drug Administration (FDA) describes ODT as " a solid dosage form containing medicinal substances which disintegrates rapidly, usually within a matter of seconds, when placed upon the tongue" (GUIDANCE FOR INDUSTRY ORALLY DISINTEGRATING TABLETS, 2008). The European Pharmacopoeia defines orodisperse as "a tablet that can be placed in the mouth where it disperses rapidly before swallowing" (EUROPEAN DIRECTORATE FOR QUALITY OF MEDICINES, 1998). 
ODTs disintegrate quickly upon contact with saliva and produce a suspension that can be easily swallowed by dogs (SASTRY et al., 2000). This is especially beneficial for young, old or sick dogs that suffer from dysphagia. So ODTs are expected to enhance compliance for dogs difficulty in swallowing because of easy administration. Palatable ODTs also increase the acceptability of drugs and compliance by various groups of dogs. Besides, due to greater surface area and faster dissolution rate after the rapid disintegration of ODTs, drug absorption and onset of action may speed up compared to conventional tablets (FU et al., 2004; HIRANI et al., 2009). Furthermore, because ODTs can be absorbed from mouth, pharynx and oesophagus, bioavailability of drugs is increased (FU et al., 2004; AGUILAR-DÍAZ et al., 2012). The pregastric absorption of drugs avoids hepatic metabolism, which also can improve the bioavailability (CLARKE et al., 2003; AGUILARDÍAZ et al., 2012). The study of CASTRO et al. (2013) showed a marked increase in drug plasma exposure and bioavailability when albendazole was given in ODTs containing solid dispersions compared with conventional tablets in dogs. ODTs also have advantages for the pharmaceutical industry through offering differentiated products and extending life cycle of drugs (BADGUJAR \& MUNDADA, 2011).

Advantages of ODTs have not been fully understood by veterinary drug researchers. So far, Zubrin $^{\circledR}$ (Tepoxalin) rapidly disintegrating tablet is the only one registration with the FDA for dogs. Zubrin $^{\circledR}$ is used to control the pain and inflammation associated with osteoarthritis of dogs. Because of easier administration, more and more veterinarians and dog owners are turning to Zubrin ${ }^{\circledR}$ to help control pain. European Medicines Agency has no relevant registration for dogs.

The method of administration of ODTs for dogs is to place the ODT into the dog's mouth and keep the mouth closed for a sufficient amount of time (in seconds), which is to ensure tablet dispersion and be swallowed. The ODT disintegrate quickly upon contact with saliva in dog's mouths. It is therefore difficult to spit out and ensures complete dosing.

The following section deals with the ideal properties of drugs, indications of ODTs, considerations in developing ODTs and development trends of ODTs for dogs.

\section{Ideal properties of drugs}

The low dose and tablet weight are beneficial to rapid disintegration of ODTs. In general, the ODTs formulations contain plenty of excipients, and high dose of drug will cause the final tablet weight too big to handle (FU et al., 2004; NAYAK \& MANNA, 2011).

The bland taste is an ideal characteristic of a drug for ODTs. Because ODTs disintegrate in the dog's mouth, the drug will come in contact with the taste buds (FU et al., 2004). An unpleasant taste in the mouth can significantly decrease the acceptance of dogs (THOMBRE, 2004). Bland taste avoids excessive increase in tablet weight due to lots of taste masking materials used in the formulation (FU et al., 2004).

In general, hydrophilic drugs are helpful to rapid disintegration of ODTs. The hydrophobic and low dose drugs, such as 10-mg dose, pose little problem. When the hydrophobic drugs are high dose, the formulation sacrifices its fast disintegrating property (FU et al., 2004). But there are many methods to prepare ODTs, sometimes the hydrophilic drugs are not beneficial to produce. During the sublimation process, the hydrophilic drugs form eutectic mixtures. Eutectic mixtures can depress freezing-point and form a glassy solid that may collapse upon drying because of loss of supporting structure (HIRANI et al., 2009).

Besides, crystal morphology, particle size, hygroscopicity, compressibility, and bulk density of a drug can significantly affect the disintegration of ODTs (FU et al., 2004). Drugs that can meet all the requirements are very little. Problems can be solved by adding superdisintegrant or special excipients, taste-masking technology, combinations with new pharmaceutical technology, using different preparation methods and so on.

\section{Indications of ODTs for dogs}

ODTs are preferred for dogs with dysphagia. Dysphagia is a common condition among dogs due to unimproved or deteriorated physiological functions or complications for example pharyngitis, growing permanent teeth and so on.

Except for dysphagia, ODTs also can be developed for dogs suffering from nausea, vomiting or motion sickness. Many dogs suffer from motion sickness even after short car trips, which is uncomfortable for dogs and inconvenient, disruptive and unpleasant for owners. ODTs are easy to dose especially in the travel and don't need be hid in food or placed at the root of the tongue. Moreover, ODTs according to veterinarian recommendation that dogs should limit food consumption before and in travel in order to prevent motion sickness.

ODTs are also particularly suitable if the medication has to be administered chronically. A typical example is Zubrin ${ }^{\circledR}$ (Tepoxalin) rapidly disintegrating tablets for the control of pain and inflammation 
associated with osteoarthritis in dogs. Additionally, antibiotic therapy for dogs may extend for weeks or months for many chronic conditions. For example, chronic skin diseases, chronic otitis, chronic dermatitis, urinary tract infections, bacterial osteomyelitis, penetrating wounds and postsurgical treatment may require long-term antibiotic administration for dogs (SUN et al., 2004; DEBOER, 1990; CHESTER, 1988; JR, 1997). Moreover, dog supplements also can be developed to ODTs, including vitamins, calcium, antioxidants, digestive enzymes and so on.

The active ingredients released by ODTs in the mouth are rapidly absorbed through the pregastric route from oral cavity, pharynx, esophagus and through gastrointestinal epithelium (BADGUJAR \& MUNDADA, 2011). Usually dissolution and absorption occur simultaneously with disintegration of medication. The fast dissolution and absorption of ODTs result in rapid action onset (BEHNKE et al., 2003; AGUILAR-DÍAZ et al., 2012). So ODTs are suitable for first-aid drugs, for example, cardiotonic, antiasthmatic, antiallergic, sedative agents and so on. Compared to the injection, administration of ODTs is simple and the owners can do by themselves in emergency circumstances.

\section{Concerns of ODTs for dogs}

When developing ODTs for dogs, dose flexibility and palatability are very important factors. Besides, packaging and price should also be special considered.

The body weight ranges from 3 to 43 $\mathrm{kg}$ for various dog breeds (IMRAN et al., 2002). Administrating the same $\mathrm{mg} \mathrm{kg}^{-1}$ dose for dogs, the total dose can range more than 12 times due to weight differences (IMRAN et al., 2002). The variation of weight can lead to under-dosing or over-dosing and then influence efficacy and safety of drugs. For greater dose accuracy and cost efficiency, ODTs should be easily split into quarters or halves by scored and developed more specifications.

Since sufficient palatability is a precondition for efficacy, palatability is claimed or regarded necessary in all oral dosage forms of veterinary medicinal products (VMP) by European Medicines Agency (COMMITTEE FOR MEDICINAL PRODUCTS FOR VETERINARY USE, 2012). ODTs disintegrate or dissolve in mouth and the active ingredients come in contact with the taste buds, therefore palatability of ODTs is more crucial to compliance (BROWN, 2001; REDDY \& GHOSH, 2002).

The simple method for improving the palatability is to add a yeast-based or a meat-based flavor to the veterinary drugs (IMRAN et al., 2002). Dogs prefer beef, pork and lamb to chicken, liver and horsemeat, and strongly prefer meat to cereal diets (THOMBRE, 2004). Beef-based Heartgard ${ }^{\circledR}$ (Ivermectin) and Heartgard Plus ${ }^{\circledR}$ (Ivermectin/Pyrantel) are widely known as a benchmark in the industry because of high palatability and acceptability by dogs (THOMBRE, 2004). The chicken flavor tablets are hypoallergenic and suitable for dogs with food allergies or atopic dermatitis (ANTIFUNGAL..., 2015).

Since many ingredients are present in the flavor systems, compatibility of active drug with the flavor, stability and analytical method become challenges for palatable ODTs (IMRAN et al., 2002).

Choosing proper packaging material and system for enhanced stability of the product is an important aspect in developing ODTs for dogs. On the one side, most of ODTs have not sufficient mechanical strength to withstand storage and transport, which often requires specialized packing. On the other side, ODTs are more sensitive to humidity. They are prone to degrade or break physical integrity at higher humidity conditions, which also needs specific packaging to ensure shelf life (HIRANI et al., 2009).

Special consideration is cost sensitivity in veterinary ODTs development (POPE \& BAGGOT, 1983; BAGGOT, 1988; IMRAN et al., 2002). Although therapy for companion animals is not usually as cost sensitive as for livestock. When pet owners face with the high price of medicine especially for a chronic condition, the expense of pet drugs is a problem. And pharmaceutical industries have to profit in a competitive business environment. So, veterinary researchers should commit to develop high quality, affordable, cost-effective ODTs for dogs by choosing appropriate preparation methods, excipients and packaging.

\section{Development trends}

ODTs can be manufactured by different methods like lyophilisation, molding, sublimation, cotton candy process or direct compression and so on (HIRANI et al., 2009; BADGUJAR \& MUNDADA, 2011). These conventional methods to manufacture ODTs have been deeply studied and reviewed. In recent years, an appropriate combination of excipients and techniques are applied to ODTs, which makes possible to obtain orally disintegrating sustained release tablets or orally disintegrating enteric tablets enhancing the dissolution rate and oral bioavailability of poorly water-soluble drugs and so on. The combination has achieved a lot of success and offered ODTs more properties and characteristics. 
Sustained release orally disintegrating tablets (SR-ODTs)

Further research into ODTs resulted in the production of sustained-release oral disintegrating tablet (SR-ODTs). SR-ODTs not only disintegrate completely in the mouth but also sustain drug release, which reduces the frequency of dosing and enhances patient compliance (ELWERFALLI et al., 2015a). Many approaches such as microencapsulation, nanoparticles, ion exchange resins and stimuli-responsive polymers have been adapted to control the drug release across ODTs (ELWERFALLI et al., 2015a).

ELWERFALLI et al. (2015b) studied chitosan particles to sustain the release of promethazine from orodispersables. Chitosan nanoparticles were prepared using ionotropic gelation and further coated. Then the coated nanoparticles and excipients were direct compressed into ODTs. Results showed the SR-ODTs could disintegrate within 40s meanwhile sustaining the drug release over 24-h.

NIKHIL et al. (2011) developed metoclopramide $\mathrm{HCl}$ orodispersible sustained release tablets by developing sustained release microspheres and then direct compression of microspheres into ODTs. Microspheres of metoclopramide $\mathrm{HCl}$ were prepared by an emulsification-solvent evaporation method using ethylcellulose as the matrix polymer. Disintegration time of ODTs was $27 \pm 3$-s. In vivo experiments demonstrated that an effective concentration in rats' plasma could be maintained for up to $20-\mathrm{h}$.

\section{Oral disintegrating tablet containing enteric-} coated pellets

Irritation of the gastrointestinal tract is a side effect after oral administration of many medicines. Development of ODTs containing entericcoated pellets might reduce or even avoid the mucosal irritation and meanwhile have the advantages of ODTs. Besides, compared with common entericcoated tablets, tablets containing enteric-coated granules are less likely to be affected by gastric emptying due to their small size (TABATA et al., 1991); in addition, damage of enteric coat to a single granule will not affect the entire dose (BALDI et al., 2003). Therefore, oral disintegrating tablet containing enteric-coated pellets is an improved and promising ODTs dosage form for dogs.

DEBUNNE et al. (2002) developed piroxicam ODTs containing enteric-coated pellets to dogs in order to avoid local gastrointestinal irritation. Results indicated that tablets rapidly disintegrated in $0.1-\mathrm{N} \mathrm{HCl}$ while retaining the gastro-resistant properties of the coated pellets.
BALDI et al. (2003) developed Lansoprazole fast disintegrating tablet (LFDT) comprising entericcoated microgranules. Each microgranule of LFDT had seven layers including an inert core, active lansoprazole layer, an inert under-coating layer, three enteric-coating layers, and an overcoating layer. After the enteric-coated microgranules released in the mouth and dissolved in the small intestine, Lansoprazole was absorbed and took effect.

\section{Oral disintegrating tablet containing solid dispersions (SDs)}

ODTs have been studied as one of the ways to increase the bioavailability of poorly water soluble drugs (AHMED et al., 2006). Solid dispersion technology is also a choice to improve the bioavailability of such drugs. Combination of ODTs with solid dispersion technology is expected to get higher bioavailability of poorly water soluble drugs.

HOSNY et al. (2013) prepared and evaluate simvastatin ODTs containing hydroxylbutyl$\beta$-cyclodextrin solid dispersions in order to enhance dissolution rate and bioavailability. CASTRO et al. (2013) studied plasma exposure of albendazole (ABZ) after administration of ODTs containing solid dispersions in dogs. Compared with conventional tablets, ABZ plasma exposure showed a marked increase when it was given in ODTs containing solid dispersions. ABZ has an aqueous solubility of less than 5-mg mL-1 and its dissolution is the rate-limiting step for absorption (WEN et al., 1993). This study combined ODTs with SDs to enhance the dissolution rate of $\mathrm{ABZ}$ and further increase its absorption rate.

\section{CONCLUSION}

ODTs are a promising dosage form for the treatment of dogs' disease. The low dose, bland taste and hydrophilic drugs are usually beneficial to prepare ODTs. In the developing ODTs for dogs, the dose flexibility, palatability, packaging and price should be concerned. ODTs can be used to dogs in cases of dysphagia, nausea, vomiting, motion sickness and so on. ODTs also are a suitable choice in chronic conditions or emergency circumstances. In the pet drug market, ODTs possess a tremendous potential because of easy administration. Furthermore, owing to ODTs flexible nature, many properties and characteristics can be incorporated into ODTs by the combination with the new technologies, such as sustained release, enteric coating, solid dispersion and so on. With continued development of new pharmaceutical technologies and excipients, we can expect the emergence of more novel ODTs for dogs. 


\section{REFERENCES}

AHMED, I. S. et al. Formulation of a fast-dissolving ketoprofen tablet using freeze-drying in blisters technique. Drug Development \& Industrial Pharmacy, v.32, n.4, p.437-442, 2006. Available from: <http://www.tandfonline.com/doi/abs/10.1080/036390405 00528913? journalCode=iddi20>. Accessed: May 20, 2016. doi: $10.1080 / 03639040500528913$.

AGUILAR-DÍAZ, J. E. et al. Predicting orally disintegrating tablets formulations of ibuprophen tablets: an application of the new SeDeM-ODT expert system. European Journal of Pharmaceutics and Biopharmaceutics, v.80, n.3, p.638-648, 2012. Available from: <http://www.sciencedirect.com/science/ article/pii/S0939641111003705>. Accessed: May 20, 2016. doi: 10.1016/j.ejpb.2011.12.012.

Antifungal tablet for dogs. Veterinary Record, v.177, p.267, 2015. Available from: <http://veterinaryrecord. bmj.com/content/177/10/267.2>. Accessed: May 20, 2016. doi:10.1136/vr.h4870.

BAGGOT, J. D. Veterinary drug formulations for animal health care: an overview. Journal of Controlled Release, v.8, n.1, p.513, 1988. Available from: <http://www. sciencedirect.com/science/ article/pii/0168365988900946>. Accessed: May 20, 2016. doi: 10.1016/0168-3659(88)90094-6.

BADGUJAR, B. P.; MUNDADA, A. S. The technologies used for developing orally disintegrating tablets: a review. Acta Pharmaceutica, v.61, n.2, p.117-139, 2011. Available from: $<$ http://www.degruyter.com/view/j/acph.2011.61.issue-2/v10007011-0020-8/v10007-011-0020-8.xml>. Accessed: May 20, 2016. doi:10.2478/v10007-011-0020-8

BALDI, F.; MALFERTHEINER, P. Lansoprazole fast disintegrating tablet: a new formulation for an established proton pump inhibitor. Digestion, v.67, n.1-2, p.1-5, 2003. Available from: $<$ http://www.karger.com/Article/FullText/70393>. Accessed: May 20, 2016. doi: 10.1159/000070393.

BEHNKE, K. et al. Mirtazapine orally disintegrating tablet versus sertraline: a prospective onset of action study. Journal of Clinical Psychopharmacology, v.23, n.4, p.358-364, 2003. Available from: $<$ https://www.researchgate.net/publication/10612754 Mirtazapine Orally_Disintegrating_Tablet_Versus_Sertraline_A_Prospective Onset_of_Action_Study>. Accessed: May 20,2016. doi:10.1097/01. jcp. 0000085408.08426 .05 .

BROWN D. Orally disintegrating tablets: taste over speed. Drug Delivery Technology, v.3, n.6, p.58-61, 2003. Available from: $<$ http://<http://www.drug-dev.com/Main/Back-Issues/OrallyDisintegrating-Tablets-Taste-Over-Speed-251.aspx $>$. Accessed: May 20, 2016.

CASTRO, S. G. et al. Comparative Plasma Exposure of Albendazole after Administration of Rapidly Disintegrating Tablets in Dogs. BioMed Research International, v.2013, n.1, p.1-7, 2013. Available from: <http://dx.doi.org/10.1155/2013/920305>. Accessed: May 20, 2016. doi: 10.1155/2013/920305.

CHESTER, D. K. Medical Management of Otitis Externa. Veterinary Clinics of North America Small Animal Practice, v.18, n.4, p.799-812, 1988. Available from: <http://www. sciencedirect.com/science/article/pii/S0195561688500839>. Accessed: May 20, 2016. doi: 10.1016/S0195-5616(88)50083-9.
CLARKE, A. et al. A new formulation of selegiline: improved bioavailability and selectivity for MAO-B inhibition. Journal of Neural Transmission, v.110, n.11, p. 1241-1255, 2003. Available from: $<$ http://link.springer.com/article/10.1007\%2Fs00702-003-0036-4>. Accessed: May 20, 2016. doi: 10.1007/s00702-003-0036-4.

COMMITTEE FOR MEDICINAL PRODUCTS FOR VETERINARY USE. Guideline on the demonstration of palatability of veterinary medicinal products. European Medicines Agency, 2012. Available from: <http://www.ema.europa.eu/docs/en_GB/ document library/Scientific guideline/2014/07/WC500170030. pdf $>$. Accessed: May 20, 2016.

DEBOER, D. J. Strategies for management of recurrent pyoderma in dogs. Veterinary Clinics of North America: Small Animal Practice, v.20, n.6, p.1509-1524, 1990. Available from: <http:// www.sciencedirect.com/science/article/pii/S0195561690501588>. Accessed: May 20, 2016. doi: 10.1016/S0195-5616(90)50158-8.

DEBUNNE, A. et al. Development and in vitro evaluation of an enteric-coated multiparticulate drug delivery system for the administration of piroxicam to dogs. European Journal of Pharmaceutics and Biopharmaceutics, v.54, n.3, p.343-348, 2002. Available from: <http://www.sciencedirect.com/science/ article/pii/S0939641102001170>. Accessed: May 20, 2016. doi: 10.1016/S0939-6411(02)00117-0.

ELWERFALLI, A. M. et al. New Generation of Orally Disintegrating Tablets for Sustained Drug Release: A Propitious Outlook. Current Drug Delivery, v.12, n.0, p.1-16, 2015a. Available from: $<$ http://www. researchgate.net/profile/Raid_Alany3/publication/273468496_New_ Generation_of_Orally_Disintegrating_Tablets_for_Sustained_Drug Release A Propitious Outlook/links/552ab24b0cf2e089a3aa0ef0.pdf $\$$. Accessed: Nov 30, 2016. doi: 10.2174/1567201812666150310151238.

ELWERFALLI, A. M. et al. Nano-engineering chitosan particles to sustain the release of promethazine from orodispersables. Carbohydrate Polymers, v.131, p.447-461, 2015b. Available from: $<$ http://dx.doi.org/10.1016/j.carbpol.2015.05.064>. Accessed: May 20, 2016. doi: 10.1016/j.carbpol.2015.05.064.

European Directorate for quality of Medicines. Pharmaeuropa, p.547, 1998. Available from: <http://www.pheur.org $>$. Accessed: May 26, 2016.

FU, Y. et al. Orally fast disintegrating tablets: developments, technologies, taste-masking and clinical studies. Critical Reviews in Therapeutic Drug Carrier Systems, v.21, n.6, p.433-475, 2004. Available from: <http://101.96.8.165/web.ics. purdue. edu/ kpark/Published\%20Papers/Fu\%2004\%20CRTDCS.pdf $>$. Accessed: Nov 30, 2016.

Guidance for Industry Orally Disintegrating Tablets. Food and Drug Administration, Center for Drug Evaluation and Research (CDER) Data Standards Manual 2008. Available from: $<$ http://www.fda. gov/downloads/Drugs/GuidanceComplianceRegulatoryInformation/ Guidances/ucm070578.pdf>. Accessed: Jan. 10, 2015.

HIRANI, J. J. et al. Orally Disintegrating Tablets: A Review. Tropical Journal of Pharmaceutical Research, v.8, n.2, p.161-172, 2009. Available from: <http://www.ajol.info/index.php/tjpr/article/ view/44525>. Accessed: May 20, 2016. doi: 10.4314/tjpr.v8i2.44525.

HOSNY, K. et al. Preparation and Evaluation of Orodispersible Tablets Containing Hydroxylbutyl- $\beta$-Cyclodextrin-Simvastatin Solid Dispersion. Tropical Journal of Pharmaceutical Research, v.12, 
n.4, p.469-476, 2013. Available from: <http://dx.doi.org/10.4314/tjpr. v12i4.4>. Accessed: May 20, 2016. doi: 10.4314/tjpr.v12i4.4.

IMRAN, A.; KASRA, K. Pharmaceutical challenges in veterinary product development. Advanced Drug Delivery Reviews, v.54, n.6, p.871-882, 2002. Available from: <http://www.sciencedirect. com/science/article/pii/S0169409X02000741>. Accessed: May 20, 2016. doi: 10.1016/S0169-409X(02)00074-1.

JR, R. E. German shepherd dog pyoderma: a prospective study of 12 dogs. Journal of the American Animal Hospital Association, v.33, n.4, p.355-363, 1997. Available from: <http://dx.doi. org/10.5326/15473317-33-4-355>. Accessed: May 20, 2016. doi: $10.5326 / 15473317-33-4-355$.

NAYAK, A. K.; MANNA, K. Current developments in orally disintegrating tablet technology. Journal of Pharmaceutical Education and Research, v.2, n.1, p.2134, 2011. Available from: <http://www.researchgate.net/ profile/Amit_Nayak2/publication/215472617_Current developments_in_orally_disintegrating_tablet_technology/ links/558807e608ae65ae5a4d9d73.pdf>. Accessed: Nov 30, 2016.

NIKHIL, K. et al. Formulation, development, and performance evaluation of metoclopramide $\mathrm{HCl}$ oro-dispersible sustained release tablet. Archives of Pharmacal Research, v.34, n.10, p.1691-1700, 2011. Available from: <http://link.springer.com/art icle/10.1007\%2Fs12272-011-1013-3>. Accessed: May 20, 2016. doi: $10.1007 / \mathrm{s} 12272-011-1013-3$.

POPE, D. G.; BAGGOT, J. D. Special considerations in veterinary formulation design. International Journal of Pharmaceutics, v.14, n.2-3, p.123-132, 1983. Available from: <http://www. sciencedirect.com/science/article/pii/037851738390087X>. Accessed: May 20, 2016. doi:10.1016/0378-5173(83)90087-X.
REDDY, L. H.; GHOSH B. R. Fast dissolving drug delivery systems: a review of the literature. Indian Journal of Pharmaceutical Sciences, v.64, n.4, p.331-336, 2002. Available from: $<$ https://www.researchgate. net/publication/281665553_Fast_dissolving_drug_delivery_ systems_A_review_of_the_literature>.Accessed: May 20, 2016.

SASTRY, S. V. et al. Recent technological advances in oral drug delivery- a review. Pharmaceutical Science \& Technology Today, v.3, n.4, p.138-145, 2000. Available from: <http://www. sciencedirect.com/science/article/pii/S1461534700002479>. Accessed: May 20, 2016. doi: 10.1016/S1461-5347(00)00247-9.

SUN, Y. et al. Issues and challenges in developing long-acting veterinary antibiotic formulations. Advanced Drug Delivery Reviews, v.56, n.10, p.1481-1496, 2004. Available from: <http:// www.sciencedirect.com/science/article/pii/S0169409X04000754>. Accessed: May 20, 2016. doi: 10.1016/j.addr.2004.02.009.

TABATA, T. et al. Effect of gastric $\mathrm{pH}$ on the absorption of a new antiulcer drug (lansoprazole) in the beagle dog. Journal of Biopharmaceutical Sciences, v.2, p.319-328, 1991. Available from: <https://www.researchgate.net/publication/292395637 Effect_of_gastric_pH_on_the_absorption_of_a_new_antiulcer_ drug_lansoprazole_in_the_beagle_dog $>$. Accessed: May 20, $201 \overline{6}$.

THOMBRE, A. G. Oral delivery of medications to companion animals: palatability considerations. Advanced Drug Delivery Reviews, v.56, n.10, p.1399-1413, 2004. Available from: <http:// www.sciencedirect.com/science/article/pii/S0169409X04000729>. Accessed: May 20, 2016. doi: 10.1016/j.addr.2004.02.012.

WEN, H. R. Diagnosis and treatment of human hydatidosis. British Journal of Clinical Pharmacology, v.35, n.6, p.565-574, 1993. Available from: <http://dx.doi.org/10.1111/j.1365-2125.1993.tb04182. $\mathrm{x}>$. Accessed: May 20, 2016. doi:10.1111/j.1365-2125. 1993.tb04182.x. 